Janusz Niczyporuk

Uniwersytet Marii Curie-Skłodowskiej w Lublinie

\title{
REGULACJA KOMPETENCJI ADMINISTRACJI LEŚNEJ
}

\section{Wprowadzenie}

Zagadnienie regulacji kompetencji jest szczególnie skomplikowane na gruncie prawa administracyjnego. Przede wszystkim trzeba najpierw zauważyć, że kompetencja jest dzisiaj pojęciem prawniczym, które nie pojawia się bezpośrednio w prawie administracyjnym. Co więcej, nie ma zgody na jednolite jego rozumienie w doktrynie prawa administracyjnego. Przeważnie wskazuje się wówczas na typowe elementy niezbędne do jego wyodrębnienia. W prawie administracyjnym podlegają natomiast regulacji pojęcia bliskoznaczne z kompetencją. Właściwie chodzi o pojęcia prawne, które dookreślają prawniczo jej istotę. Innymi słowy mamy do czynienia z pojęciami funkcjonalnie powiązanymi z kompetencją, takimi jak: cel, zadanie, sprawa, zakres działania, działy administracji rządowej, właściwość, formy działania administracji. Wszystkie razem współtworzą one prawnicze ujęcie kompetencji, ponieważ każde z nich wyjaśnia określony jej aspekt. Dlatego nie wolno nigdy utożsamiać kompetencji z jednym tylko pojęciem wobec niej bliskoznacznym. Ponadto należy jeszcze pamiętać, że pojęcie kompetencja przenika całe prawo administracyjne. W związku z tym powinno zawsze pojawiać się równocześnie $\mathrm{w}$ ramach prawa administracyjnego: ustrojowego, materialnego i proceduralnego. Punktem wyjścia dla regulacji definicji pojęcia kompetencja jest tutaj prawo administracyjne materialne.

\section{Pojęcie „kompetencja”}

$\mathrm{Z}$ całą pewnością należy pojęcie kompetencja łączyć z podmiotami administrującymi, natomiast wykluczyć jego związek z podmiotami administrowanymi. Jeżeli mówi się w tym kontekście o podmiotach administrowanych, to wypada raczej odwoływać się do pojęcia prawa podmiotowe. Podmioty administrujące tworzą zwykle wewnętrzne jednostki organizacyjne podmiotów administracji. Tradycyjnie mówi 
się tutaj o organach administracji publicznej, przy tym należy je rozumieć w znaczeniu funkcjonalnym. Zatem nie chodzi jedynie o organy administracji rządowej. Najczęściej uznaje się za podmioty administracji: państwo, korporacje publicznoprawne, zakłady publicznoprawne, fundacje publicznoprawne, spółki publiczne, fundusze publiczne, przedsiębiorstwa państwowe, agencje rządowe oraz inne podmioty $\mathrm{z}$ funkcjami zleconymi. W konsekwencji podmioty administracji możemy niemal wyłącznie zaliczyć do jednostek organizacyjnych, zarówno posiadających osobowość prawną, jak i nieposiadających osobowości prawnej. Natomiast pojęcia bliskoznaczne wobec kompetencji nie muszą wcale łączyć się z podmiotami administrującymi, chociaż ma to zwykle miejsce. Tradycyjnie wypada więc analizować rozumienie kompetencji w płaszczyźnie podmiotowej badania administracji publicznej.

Ujęcie doktrynalne kompetencji musi oczywiście zostać skonfrontowane z praktyką jego funkcjonowania w regulacji prawa administracyjnego. Najlepiej sprostać temu poprzez opracowanie studium konkretnego przypadku. Z punktu widzenia istoty prowadzonych teraz rozważań wydaje się interesujące opracowanie regulacji dotyczących kompetencji administracji leśnej. Przede wszystkim mamy tutaj do czynienia z wyraźnym oparciem pojęcia kompetencja na wielu powiązanych z nią pojęciach bliskoznacznych. Cały system funkcjonalnych powiązań między nimi daje wtedy okazję do wyprowadzenia potrzebnych uogólnień. Tym bardziej okazuje się to niezbędne, że jest niezwykle trudno przeprowadzić rozgraniczenie w definicji pojęcia kompetencja i pojęć do niej bliskoznacznych, gdy zwłaszcza nie mają sformułowanych definicji legalnych. W prawie administracyjnym pojęcia bliskoznaczne do kompetencji są używane niekonsekwentnie, co dodatkowo utrudnia ich konieczną delimitację. Na zasadność ich odróżnienia wskazują często spotykane zwroty pojęciowe, jak chociażby: sprawy z zakresu, zadania z zakresu, właściwość do spraw. Natomiast pojęcie administracja leśna należy wówczas rozumieć jako zbiór podmiotów administrujących, którym została przypisana kompetencja odnośnie lasów. Zasadniczo musi to zatem dotyczyć regulacji prawnej o charakterze ustawowym, która ma charakter wiodący dla zagadnień związanych z lasami. ${ }^{1}$

W związku z tym kompetencję należy tutaj rozumieć jako oparte na przepisach prawa administracyjnego upoważnienie i obowiązek działania organu administracji publicznej. ${ }^{2}$ Za podstawowe elementy kompetencji wypada zatem uznać upoważnienie i obowiązek. Zawsze istnieje również ścisła współzależność między przyznanymi upoważnieniami i nałożonymi obowiązkami. Przez upoważnienie należy wówczas rozumieć zdolność organu administracji publicznej do skonkretyzowanego aktualizowania, w drodze odpowiedniego postępowania, potencjalnego obowiązku 
działania opartego na przepisach prawa. ${ }^{3} \mathrm{Z}$ kolei obowiązek polega na stałym baczeniu organu administracji publicznej, czy nie zachodzą okoliczności, w których należy skorzystać z odpowiedniego upoważnienia oraz na zobowiązaniu organu administracji publicznej do realizacji odpowiedniego upoważnienia w sytuacjach tego wymagających. ${ }^{4} \mathrm{Z}$ tego punktu widzenia można już konkretnie wskazać na element uprawnienia w kompetencji nadleśniczego, który wprowadza okresowy zakaz wstępu do lasu stanowiącego własność Skarbu Państwa, w razie gdy pojawią się oczywiście szczególne okoliczności uzasadniające takie postępowanie. ${ }^{5}$ Natomiast element obowiązku w kompetencji nadleśniczego spotykamy, gdy ciąży na nim obowiązek ustanawiania i utrzymywania znaków w stosunku do lasów będących w zarządzie Lasów Państwowych. ${ }^{6}$

\section{Zadania a kompetencje}

Z całą pewnością cele i zadania są stanem rzeczy osiąganym przez organ administracji publicznej za pomocą przysługujących mu kompetencji. Przy tym należy wyraźnie odróżniać zadania organu administracji publicznej od jego celów. ${ }^{7}$ Przez zadanie organu administracji publicznej wypada więc rozumieć oparty na prawie administracyjnym obowiązek działania organu administracji publicznej, aby można było zrealizować wytyczony w nim cel działania organu administracji publicznej. ${ }^{8}$ Tymczasem cel jest taką wartością podstawową w prawie administracyjnym, którego realizacja leży w ostatecznym zamierzeniu organu administracji publicznej, co ma ostatecznie wynikać z określonych w nim zadań organu administracji publicznej. ${ }^{9}$ Dlatego w celu promocji trwale zrównoważonej gospodarki leśnej oraz ochrony przyrody w lasach Dyrektor Generalny Lasów Państwowych może, w drodze zarządzenia, ustanawiać leśne kompleksy promocyjne. ${ }^{10} \mathrm{Z}$ drugiej strony można równocześnie dodać, że Dyrektor Generalny Ochrony Środowiska może powierzyć, w drodze porozumienia, dyrektorowi regionalnej dyrekcji Lasów Państwowych wykonywanie zadań poza terenami jego działania, związanych z realizacją planu zadań ochronnych lub planu ochrony obszaru Natura $2000 .^{11}$

Konkretne zadanie wymagające rozwiązania, przez organ administracji publicznej za pomocą przysługującej mu kompetencji, określa się najczęściej mianem

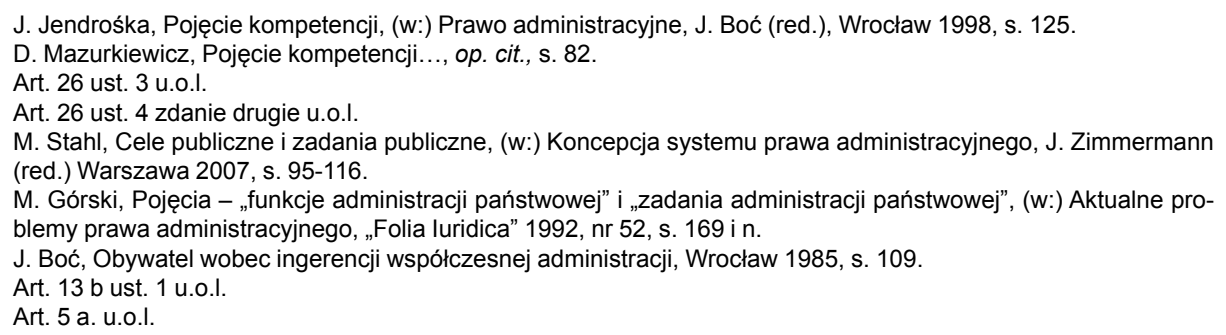


sprawy. Tak więc sprawę można ostatecznie zdefiniować jako kwestię istnienia stanu faktycznego, opisanego w hipotezie normy prawa administracyjnego, wymagającej dla uwolnienia swej mocy wiążącej autorytatywnej konkretyzacji, dokonanej w formie aktu wydanego przez właściwy organ administracji publicznej. ${ }^{12}$ Ponadto kompetencje organu administracji publicznej mogą tylko być wykorzystywane w jego zakresie działania. Tym samym zakres działania należy tutaj rozumieć jako rodzaje spraw opartych na przepisach prawa administracyjnego, w których organ administracji publicznej ma upoważnienie i obowiązek działania. Przeważnie zakres działania organu administracji publicznej jest utożsamiany z jego właściwością rzeczową, a co tyczy się ministra również z działem administracji rządowej. Gdyż starosta może, $w$ drodze porozumienia, powierzyć prowadzenie $w$ jego imieniu spraw z zakresu nadzoru w lasach niestanowiących własności Skarbu Państwa, w tym wydawanie decyzji administracyjnych w pierwszej instancji, nadleśniczemu Lasów Państwowych. ${ }^{13}$ Zaś dla lasów rozdrobnionych o powierzchni do 10 ha, niestanowiących własności Skarbu Państwa, zadania z zakresu gospodarki leśnej określa decyzja starosty wydana na podstawie inwentaryzacji stanu lasów. ${ }^{14} \mathrm{Z}$ kolei nadzór nad Lasami Państwowymi sprawuje minister właściwy do spraw środowiska. ${ }^{15}$

\section{Związek między organem administracji publicznej a powierzonymi mu zadaniami}

Związek między organem administracji publicznej a powierzonymi mu zadaniami, lub szerzej jeszcze ujmując zakresem działania, jest identyfikowany jako właściwość w prawie administracyjnym. Właściwość służy więc do określenia kompetentnego organu administracji publicznej. Przy tym należy jeszcze podnieść, że kompetencja organu administracji publicznej została ukształtowana w prawie administracyjnym materialnym, podczas gdy właściwość ma swoje korzenie w prawie administracyjnym proceduralnym. Kompetentny organ administracji publicznej jest określany przez właściwość: rzeczową, miejscową, instancyjną. Stąd Dyrektor Generalny Lasów Państwowych reprezentuje Skarb Państwa w stosunkach cywilnoprawnych, w zakresie swojego działania. ${ }^{16}$ Natomiast starosta właściwy ze względu na położenie gruntu objętego zalesieniem dokonuje oceny udatności upraw w czwartym lub piątym roku od zalesienia gruntu rolnego oraz przekwalifikuje z urzędu grunt rolny na leśny, jeżeli zalesienia gruntu dokonano na podstawie przepisów o wspieraniu rozwoju obszarów wiejskich ze środków pochodzących z Sekcji Gwarancji Europejskiego Funduszu Orientacji i Gwarancji Rolnej lub na podstawie przepisów

T. Kiełkowski, Sprawa administracyjna, Kraków 2004, s. 35.

Art. 5 ust. 3 u.o.l.

Art. 19 ust. 3 u.o.l.

Art. 4 ust. 4 u.o.l.

Art. 33 ust. 3 pkt 1 u.o.I. 
o wspieraniu rozwoju obszarów wiejskich z udziałem środków Europejskiego Funduszu Rolnego na rzecz Rozwoju Obszarów Wiejskich. ${ }^{17}$

Naturalnie kompetencja jest zawsze wykonywana w określonych formach działania administracji. W tym kontekście formę działania administracji należy dalej uznać za pewien typ powtarzających się działań organu administracji publicznej w prawie administracyjnym. Co prawda, katalog form działania administracji pozostaje ciągle otwarty, tym niemniej wolno do niego zaliczyć: stanowienie powszechnie obowiązujących przepisów, wydawanie aktów administracyjnych, zawieranie umów, zawieranie porozumień, prowadzenie działalności społeczno-organizatorskiej i wykonywanie czynności materialno-technicznych. ${ }^{18}$ Oczywiście chodzi tutaj o formy działania administracji właściwe zarówno dla prawa publicznego, jak również przynależne dla prawa prywatnego. Zatem minister właściwy do spraw środowiska, w drodze decyzji, uznaje las za ochronny lub pozbawia go tego charakteru, na wniosek Dyrektora Generalnego, zaopiniowany przez radę gminy - w odniesieniu do lasów stanowiących własność Skarbu Państwa. ${ }^{19}$ Następnie starosta może powierzyć, w drodze porozumienia, dokonanie oceny udatności upraw nadleśniczemu. ${ }^{20}$ Dalej nadleśniczy może, na podstawie umowy z właścicielem lasu, organizować wykonywanie zadań gospodarczych w lesie, łącznie ze sprzedażą drewna. ${ }^{21}$

\section{Podsumowanie}

Z punktu widzenia oceny regulacji dotyczących kompetencji administracji leśnej należy wreszcie zauważyć, że powinna ona przestrzegać wymogów: zachowania wyłączności kompetencyjnej, przestrzegania pojemności kompetencyjnej i zapewnienia przejrzystości kompetencyjnej. ${ }^{22}$ Zachowanie wyłączności kompetencyjnej ma wówczas oznaczać, iż do podjęcia określonego działania upoważniony i zobowiązany jest wyłącznie jeden organ administracji leśnej. Z kolei przestrzeganie pojemności kompetencyjnej powinno tutaj powodować, że ilość upoważnień i obowiązków działania organów administracji leśnej jest zawsze odgórnie zawężona. Zapewnienie przejrzystości kompetencyjnej wypada teraz łączyć z tym, że upoważnienia i obowiązki działania organu administracji leśnej bywają określone jednoznacznie. Te wymogi są zasadniczo przestrzegane w regulacjach dotyczących kompetencji administracji leśnej. Aczkolwiek można równocześnie podać liczne przykłady, które wskazują na świadomie wprowadzone od nich wyjątki, czyli odstępujące od zachowania wymogu przejrzystości kompetencyjnej. Przede wszystkim

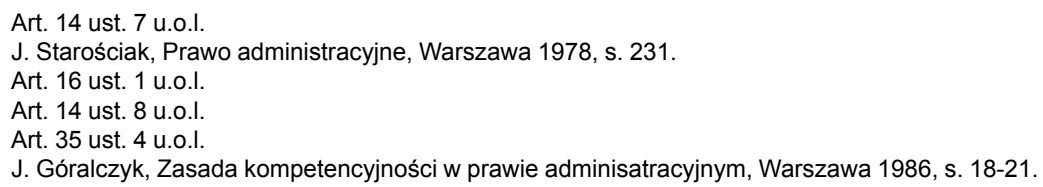


wynika to $z$ koncepcji jedności leśnictwa, bez względu na formę ich własności. ${ }^{23}$ W związku z tym nie ma dzisiaj odrębnego uregulowania problematyki lasów państwowych i niepaństwowych. ${ }^{24}$ Ponieważ tych odrębności jest w praktyce tak dużo, to podział na lasy stanowiące własność Skarbu Państwa i inne lasy zachował swoje znaczenie. ${ }^{25}$ 


\section{REGULATION COMPETENCE OF FOREST ADMINISTRATION}

Recognition of doctrinal competence should be confronted with the practice of its functioning in the regulation of administrative law. In this context, it is now interesting to develop the regulation competence of forest administration. First of all, we are dealing here with a clear backrest competence in the many related concepts synonymous with it. Of course, in terms of the concept of functionality related to the competence, such as objective task, issue, the scope of activities of government departments, property, forms of administrative action. The whole system of functional relationships between them then gives the opportunity to derive the necessary generalizations. Among them is revealed especially the demand for transparency and improved administrative competence, which also applies to the forest administration.

Keywords: regulation, competence, forest administration, administrative law 